\title{
EFFECTS OF DIETARY VITAMIN E SUPPLEMENTATION ON HAEMATOLOGICAL PARAMETERS, SERUM VITAMIN E AND LIPID OXIDATION OF MAHALI GOATS IN LIBYA
}

\author{
Z. ZAYED ${ }^{1} ;$ N. ESTUTY ${ }^{2}$ AND S. ABDELATTI ${ }^{3}$ \\ ${ }^{1}$ Department of Physiology, Faculty of Veterinary Medicine, Azzaytuna University. \\ ${ }^{2}$ Libyan Authority For Scientific Research, Libyan Olive Tree Research Centre. \\ ${ }^{3}$ Department of Basic Science, Faculty of Veterinary Medicine, Sudan \\ University of Science and Technology
}

Received: 27 June 2021; Accepted: 30 July 2021

\begin{abstract}
This study aimed to investigate the impact of dietary vitamin E (DL- $\alpha$-tocopherol acetate) on growth performance, amount of malondialdehyde in serum, serum vitamin E level, haematological and biochemical metabolites of Mahali goat kids. Twenty four male kids weighing 10-15 kg were randomly allocated to one of four groups to receive four different treatments of vitamin E. Group one (control, C), $2^{\text {nd }}$ group received $300 \mathrm{IU}$ vitamin E $(300 \mathrm{E})$, $3^{\text {rd }}$ group received $500 \mathrm{IU}$ vitamin E $(500 \mathrm{E})$, and $1000 \mathrm{IU}$ vitamin $\mathrm{E}(1000 \mathrm{E})$ in the $4^{\text {th }}$ group. The animals were housed in separated pens and fed concentrate with a barley hay diet. Blood samples were weekly collected through the jugular vein for haematological and biochemical analysis. The evaluation of malondialdehyde and vitamin E content in serum was performed. The result revealed that vitamin $\mathrm{E}$ significantly increased red blood cells (RBC), Haemoglobin (HB), white blood cells (WBC), and differential white blood cells. Vitamin E significantly $(\mathrm{p}<0.001)$ increased level of vitamin $\mathrm{E}$ in serum, while, reduced total protein (TP), albumin, alanine transaminase (ALT), aspartate transaminase (AST), high density lipoproteins (HDL), cholesterol, and malondialdehyde (MDA) in the serum. In conclusion, dietary supplementation of vitamin E may effectively improved haematological, biochemical parameters, serum $\alpha$-tocopherol content as well as malondialdehyde of Mahali goat kids.
\end{abstract}

Keywords: Vitamin E, oxidative stability, goats, Haematological.

\section{INTRODUCTION}

Vitamin $\mathrm{E}$ is an essential dietary nutrient that played a crucial factor in the health and development of animals (Castellini et al., 2007).

Corresponding author: N. Estuty

E-mail address: nestuty@gmail.com

Present address: Libyan Authority For Scientific

Research, Libyan Olive Tree Research Centre.
It can act as an antioxidant and prevents oxidation of polyunsaturated fatty acids (Traber and Stevens, 2011). The beneficial effects of $\alpha$-tocopherol on health of the body were often attributed to reducing oxidative damage (Aitken et al., 2009). The inclusion of vitamin $\mathrm{E}$ in the diet increased $\mathrm{HB}$ and total leukocyte count in the blood of broiler chickens (Shivappa et al., 2013). One sign of oxidative problems was lipid peroxidation of RBC cell membranes which reduced life spans of RBC and caused anemia (Ansari et al., 
2015). Nutrition, heat, age, gender, race, diseases, muscle activity, season, and stress have all been shown to influence blood parameters in farm animals (Khan et al., 2009). Low levels of vitamin $\mathrm{E}$ and increased mortality rate have been reported in the newborn kids despite pregnant goats had an acceptable levels of vitamin $\mathrm{E}$ (Smolders et al., 2012).

Controversial results were reported on the effect of vitamin $\mathrm{E}$ on haematological and biochemical parameters. Yusuf et al. (2019), reported that dietary supplementation of $200 \mathrm{mg} \alpha$-tocopherol significantly enhanced immune response, health status, reduced level of albumin, cholesterol, ALT, and thiobarbituric acid (TBARS) in goat kids. Whereas, another research showed that supplementation of vitamin $\mathrm{E}$ had non-significant effects on ALT, AST level, and macrophage, with maintain of $\mathrm{WBC}, \mathrm{RBC}$ count, $\mathrm{HB}$, reduced $\mathrm{TP}$, and albumin in heat-stressed broiler chickens (Gharieb and Moursi., 2013). Moreover, (Adebiyi et al., 2014) reported that vitamin $\mathrm{E}$ reduced $\mathrm{TP}$, albumin, LDL, cholesterol, and malondialdehyde (MDA) after supplementation of vitamin E. Although there are many studies on the effects of vitamin $\mathrm{E}$ on lambs, calves, and chicken, there are very few experiments have been undertaken to study the effects of vitamin $\mathrm{E}$ on goats and kids (Ramadan et al., 2018). However, serum concentrations of metabolites such as cholesterol, TP, albumin are commonly used to assess the nutritional status of cattle (Xuan et al., 2018). The present study aimed to investigate the impact of vitamin $\mathrm{E}$ on hematological, biochemical, serum vitamin $\mathrm{E}$, and serum malondialdehyde content of Mahali goat kids.

\section{MATERIALS AND METHOD}

\section{Animals}

The experiment was carried out on 24 male kids (Mahali breed) 3-4 months of age, average life weight $10-15 \mathrm{~kg}$, purchased from the local market. The study was conducted on a private farm in Tarhuna city about $80 \mathrm{~km}$ south of Tripoli. The animals were rested, ear tagged, and then divided randomly into four groups according to the treatment of vitamin E. Each animal was allocated in an individual well ventilated shaded separate pen, and allowed visual contact with each other with free access to water. All diets with hay to concentrate ration formulated to meet all nutrient requirements for goat kids (NRC, 2007). The concentrate ration consists of $48 \%$ crushed maize grain, $26 \%$ soybean meal, $24 \%$ wheat bran, $0.5 \%$ mineral mixture, $1.4 \%$ limestone, and $0.1 \%$ vitamins and minerals, the ration contain $46 \mathrm{IU} / \mathrm{kg}$ vitamin $\mathrm{E}$.

\section{Adaptation period}

Kids had an adaptation period for two weeks before the study. They were fed a basal diet of a 75:25 mixture of hay and concentrate.

\section{Treatments}

The kids have received particular levels of $\alpha$-tocopherol with concentrate and hay for each group as follows: control group (C), $2^{\text {nd }}$ group $(300 \mathrm{E})$ received $300 \mathrm{IU}$ vitamin $\mathrm{E} /$ day, $3^{\text {rd }}$ group $(500 \mathrm{E})$ received $500 \mathrm{IU}$ vitamin $\mathrm{E} / \mathrm{day}$, and $4^{\text {th }}$ group $(1000 \mathrm{E})$ had 1000 IU vitamin E/ day, the experiment lasted for 2 months.

\section{Haematological analysis}

Blood samples were weekly collected, about $10 \mathrm{ml}$ of blood was drawn from the jugular vein of each kid, $4 \mathrm{ml}$ of each sample was released into vacuum tubes for evaluation of complete blood count (CBC) using Mindray hematology analyzer BC 2800aa (C2013 Shenzhen Mindray Bio-Mindray Electronics Co., Ltd,).

\section{Biochemical analysis}

Serum was recovered by centrifugation (10 $\mathrm{m}$ at $3000 \mathrm{rpm}$ ) for evaluation of total proteins, albumin, LDL, HDL, cholesterol, ALT, and AST using Mindray hematology analyzer BC 2800aa. The part of the serum samples stored at $-20 \mathrm{C}$ for evaluation of 
MDA and $\alpha$-tocopherol content in the serum. Both were measured by high-performance liquid chromatography, which was performed in the Animal Health Research Center in the Arab Republic of Egypt, following the method of Hoehler et al. (1998) for vitamin E content in the serum. Whereas, method of Buege and Aust, (1978) for evaluation of MDA.

\section{Statistical analysis}

The data obtained from the study were subjected to one-way analysis of variance ANOVA, Minitabe (release No.; South College, Pa.). Grouping information using Tukey method was used for post-hoc analysis at $95.0 \%$ confidence level. Two factors with repeated measures on one factor (weeks). Correlation and regression analysis was used to establish the relationships between dietary concentrations of $\alpha$ tocopherol acetate and blood parameters. Comparison made using ANOVA to establish effects of $\alpha$-tocopherol on blood parameters.

\section{RESULTS}

\section{Blood analysis}

The effects of the three levels of vitamin $\mathrm{E}$ on blood parameters are presented in Table (1). Vitamin $\mathrm{E}$ reduced the number of RBC in the three experimental groups in the first three weeks of the trial. Afterward, there was a significant $(p<0.05)$ elevation in the number of RBC through the rest of the weeks of the trial in the three groups compared with the control. Regarding the impact of $\alpha$-tocopherol on $\mathrm{HB}$, it caused a decline of HB level in the three $\alpha$-tocopherol supplemented groups at the first three weeks of the trial. Subsequently, the level of HB had significantly $(\mathrm{p}<0.05)$ increased again in the vitamin $\mathrm{E}$ supplemented groups to the end of the trial. In addition, vitamin $\mathrm{E}$ significantly $(\mathrm{p}<0.001)$ reduced the percentage of PCV in the treated groups. However, there was a significant rise $(\mathrm{p}<0.05)$ in the number of WBC in $300 \mathrm{E}$ and 500 E groups compared with the control. Whereas, $\alpha$-tocopherol at level $1000 \mathrm{E}$ had no significant $(\mathrm{p}>0.05)$ effect on WBC. Vitamin $\mathrm{E}$ had a highly significant $(\mathrm{P}<0.001)$ elevation in the number of monocytes and eosinophils, while a non-significant increase in the number of lymphocytes. Vitamin E supplementation had a significant $(\mathrm{p}<0.05)$ increase in number of basophils. Whereas, vitamin $E$ caused a significant $(\mathrm{p}<0.05)$ decrease in number of neutrophils in $500 \mathrm{E}$ and 1000 E groups. While, a non significant decrease in number of neutrophils in $300 \mathrm{E}$ group compared with the control.

\section{Blood biochemicstry}

Data in Table (2) revealed that $\alpha$-tocopherol supplementation caused significant $(\mathrm{P}<0.001)$ decrease in the concentration of TP in the treated groups compared with the control. Vitamin E significantly $(\mathrm{p}<0.001)$ reduced level of albumin in the vitamin $\mathrm{E}$ supplemented groups compared with the control. There was a significant decrease $(p<0.05)$ in ALT level in $500 \mathrm{E}$ treated group, whereas, a non-significant impact in $300 \mathrm{E}$ and $1000 \mathrm{E}$ groups. Moreover, vitamin $E$ caused significant lowring $(\mathrm{p}<0.05)$ in AST content in $300 \mathrm{E}$ and $500 \mathrm{E}$ treatments compared with the control, while there was a non-significant reduce of AST in 1000 E treatment.

Dietary $\quad \alpha$-tocopherol significantly minimized $(\mathrm{P}<0.001)$ level of cholesterol in the three treated groups compared with the control. Regarding LDL, there was a nonsignificant impact of LDL on the vitamin $\mathrm{E}$ supplemented groups compared with the control. Turning to HDL, $\alpha$-tocopherol caused a significant $(\mathrm{P}<0.001)$ reduction in HDL content in the all treated groups compared with the control. Furthermore, vitamin E significantly ( $p<0.001)$ boosted the amount of vitamin $E$ in the serum of the three groups of $\alpha$-tocopherol compared with the control. 
Table 1: Effects of different dietary levels of vitamin $E$ on blood parameters of male goat kids $(n=6)$.

\begin{tabular}{|c|c|c|c|c|c|c|}
\hline Parameters & Control & $300 \mathrm{E}$ & $500 \mathrm{E}$ & $1000 \mathrm{E}$ & SED & $\begin{array}{c}\text { Statistical } \\
\text { Significant }\end{array}$ \\
\hline \multicolumn{7}{|l|}{$\begin{array}{c}\text { Hematological } \\
\text { Parameters }\end{array}$} \\
\hline $\mathrm{RBC}\left(\times 10^{12} / \mu \mathrm{l}\right)$ & $2.1^{\mathrm{a}}$ & $1.4^{\mathrm{b}}$ & $1.6^{\mathrm{ab}}$ & $1.4^{\mathrm{b}}$ & 0.19 & $\mathrm{p}<0.05$ \\
\hline $\mathrm{HB}(\mathrm{g} / \mathrm{dl})$ & $12.0^{\mathrm{a}}$ & $10^{\mathrm{bc}}$ & $10.8^{\mathrm{ab}}$ & $10.4^{\mathrm{bc}}$ & 0.5 & $\mathrm{P}<0.05$ \\
\hline PCV $(\%)$ & $5.0^{\mathrm{a}}$ & $3.1^{\mathrm{b}}$ & $3.3^{\mathrm{b}}$ & $3.3^{\mathrm{b}}$ & 0.5 & $\mathrm{P}<0.001$ \\
\hline $\mathrm{WBC}\left(\times 10^{9} / \mathrm{L}\right)$ & $44^{\mathrm{c}}$ & $56^{\mathrm{b}}$ & $62^{a}$ & $42^{\mathrm{c}}$ & 6.8 & $\mathrm{p}<0.05$ \\
\hline Neutrophil (cells $\mu 1^{-1}$ ) & $0.42^{\mathrm{a}}$ & $0.34^{\mathrm{a} b}$ & $0.29^{\mathrm{bc}}$ & $0.31^{\mathrm{bc}}$ & 0.06 & $\mathrm{P}<0.05$ \\
\hline Eosinophil (cells $\mu \mathrm{l}^{-1}$ ) & $0.08^{c}$ & $0.07^{\mathrm{c}}$ & $0.13^{\mathrm{a}}$ & $0.10^{\mathrm{b}}$ & 0.03 & $\mathrm{P}<0.001$ \\
\hline Basophil (cells $\mu 1^{-1}$ ) & $0.014^{\mathrm{c}}$ & $0.016^{\mathrm{bc}}$ & $0.023^{\mathrm{a}}$ & $0.02^{\mathrm{ab}}$ & 0.004 & $\mathrm{P}<0.05$ \\
\hline Monocyte (cells $\left.\mu 1^{-1}\right)$ & $0.21^{\mathrm{d}}$ & $0.37^{\mathrm{c}}$ & $0.56^{\mathrm{b}}$ & $0.72^{\mathrm{a}}$ & 0.22 & $\mathrm{p}<0.001$ \\
\hline Lymphocyte (cells $\left.\mu \mathrm{l}^{-1}\right)$ & $0.62^{\mathrm{a}}$ & $0.73^{\mathrm{a}}$ & $0.75^{\mathrm{a}}$ & $0.64^{\mathrm{a}}$ & 0.06 & N.S. \\
\hline
\end{tabular}

RBC: red blood cell, HB: haemoglubin, WBC: white blood cells, PCV:pack cell volume. Values in the same raw labeled with different superscript letters (a-d) differ significantly.

Table 2: Effects of different dietary levels of vitamin $\mathrm{E}$ on serum biochemical parameters of male goat kids $(n=6)$.

\begin{tabular}{lcccccc}
\hline Parameters & Control & $300 \mathrm{E}$ & $500 \mathrm{E}$ & $1000 \mathrm{E}$ & SED & $\begin{array}{c}\text { Statistical } \\
\text { Significant }\end{array}$ \\
\hline $\begin{array}{l}\text { Biochemical analysis } \\
\text { Total protein }(\mathrm{g} / \mathrm{dl})\end{array}$ & $7.0^{\mathrm{a}}$ & $6.3^{\mathrm{cd}}$ & $6.5^{\mathrm{bc}}$ & $6.7^{\mathrm{b}}$ & 0.29 & $\mathrm{p}<0.001$ \\
\hline Albumin $(\mathrm{g} / \mathrm{dl})$ & $5.4^{\mathrm{a}}$ & $4.5^{\mathrm{c}}$ & $4.9^{\mathrm{bc}}$ & $4.9^{\mathrm{b}}$ & 0.27 & $\mathrm{p}<0.001$ \\
\hline ALT $(\mathrm{u} / \mathrm{l})$ & $23^{\mathrm{ab}}$ & $22^{\mathrm{bc}}$ & $20^{\mathrm{c}}$ & $25^{\mathrm{a}}$ & 2.9 & $\mathrm{p}<0.05$ \\
\hline AST $(\mathrm{u} / \mathrm{l})$ & $42^{\mathrm{a}}$ & $31^{\mathrm{c}}$ & $37^{\mathrm{b}}$ & $38^{\mathrm{ab}}$ & 5.2 & $\mathrm{P}<0.05$ \\
\hline Cholesterol $(\mathrm{mg} / \mathrm{dl})$ & $103^{\mathrm{a}}$ & $87^{\mathrm{b}}$ & $83^{\mathrm{b}}$ & $86^{\mathrm{b}}$ & 12.5 & $\mathrm{p}<0.001$ \\
\hline LDL $(\mathrm{mg} / \mathrm{dl})$ & $75.9^{\mathrm{a}}$ & $76^{\mathrm{a}}$ & $74.7^{\mathrm{a}}$ & $81.6^{\mathrm{a}}$ & 5.9 & $\mathrm{P}>0.05$ \\
\hline HDL $(\mathrm{mg} / \mathrm{dl})$ & $31^{\mathrm{a}}$ & $29^{\mathrm{b}}$ & $28.5^{\mathrm{bc}}$ & $28^{\mathrm{c}}$ & 1.6 & $\mathrm{P}<0.001$ \\
\hline Vit E in serum $(\mu \mathrm{g} / \mathrm{ml})$ & $4.1^{\mathrm{d}}$ & $5.2^{\mathrm{ab}}$ & $5.3^{\mathrm{a}}$ & $5.1^{\mathrm{bc}}$ & 0.16 & $\mathrm{p}<0.001$ \\
\hline $\begin{array}{l}\text { MDA in serum } \\
\text { (n.molml) }\end{array}$ & $7.2^{\mathrm{a}}$ & $6.4^{\mathrm{b}}$ & $4.7^{\mathrm{c}}$ & $3.7^{\mathrm{d}}$ & 0.07 & $\mathrm{P}<0.001$ \\
\hline ALT: alang & & & & & & \\
\hline
\end{tabular}

ALT: alanine transaminase, AST: aspartate transaminase, HDL: high density lipoproteins, LDL: low density lipoproteins,

NS: non-significant, MDA: malondialdehyde. Values in the same raw labeled with different superscript letters

(a-d) differ significantly. 
On the other hand, vitamin E significantly $(p<0.001)$ reduced the amount of MDA in the serum in all vitamin $\mathrm{E}$ supplemented groups compared with the control. Group $1000 \mathrm{E}$ was the most effective treatment followed by $500 \mathrm{E}$ and $300 \mathrm{E}$ group, the differences between vitamin $\mathrm{E}$ groups were significant.

\section{DISCUSSION}

There is an essential need for antioxidant supplementation in the diet of goats to protect antioxidant balance in the blood (Minetti et al., 2007). The result confirmed the important of antioxidant supplementation in increasing the concentration of RBC. The effects of the three levels of vitamin $E$ on RBC significantly $(\mathrm{p}<0.05)$ increased $R B C$ count in all treatments of vitamin $\mathrm{E}$ compared with the control. This was agreed with Yusuf et al. (2019) in goat kids. In contrast, it was disagreed with Netto et al. (2017) who suggested that vitamin E had no significant impact on RBC count in Saanen goats. Regarding haemoglobin, the inclusion of the different amounts of vitamin $E$ had significantly $(p<0.05)$ raised HB concentration in the vitamin E supplemented groups compared with the control. This result was in accordance with Yusuf et al. (2019) in goat kids. Vitamin E reduced the level of PCV in the three groups of $\alpha$ tocopherol compared with the control. This outcome was agree with the study of (Yusuf et al., 2019). The level of PCV in this study was very low, this could be due to the fluctuation in level of PCV in goat kids in less than one year age (Egbe-Nwiyi et al., 2000).

Supplemntation of antioxidants have no deleterious influence on immune response of goats (Yusuf et al., 2019). The two groups $300 \mathrm{E}$ and $500 \mathrm{E}$ significantly boosted the level of WBC, which in concur with Shokrollai et al. (2013) in goats kids. In contrast, $\alpha$-tocopherol at $1000 \mathrm{IU}$ had no significant effect on number of WBC which agree with Netto et al. (2017) in Saanen goats. The number of WBC in this study was high, this might be due to the kids possess protective system provides a potent defense against diseases (Opera et al., 2010). In the current study vitamin $\mathrm{E}$ had no significant influence on number of lymphocytes in the vitamin E supplemented groups. This was in agreement with study of (Yusuf et al., 2019). Supplementation of antioxidants helped in regulation of immune response to parasitic infection and allergy (Sokol and Medzhitov, 2010). Vitamin E had a significant increase on basophils in both treated groups $500 \mathrm{E}$ and $1000 \mathrm{E}$. while, vitamin $\mathrm{E}$ had a non significant impact on number of basophils in $300 \mathrm{E}$ group , this was agree with the result of (Yusuf et al., 2019).

From the table (2), vitamin $\mathrm{E}$ caused a significant $\quad(\mathrm{P}<0.001) \quad$ depletion in concentration of TP in the three groups of $\alpha$ tocopherol treatment. This was in disagreement with Ziaei, (2015) who concluded that $\alpha$-tocopherol had a nonsignificant effect on level of TP of Raieni goats. However, vitamin E significantly $(\mathrm{P}<0.001)$ reduced albumin level in the three treatments of $\alpha$-tocopherol compared with the control. This was in agreement with Ramadan et al. (2018) in goats, whereas, was in disagreement with Rahmani et al. (2015), who reported that vitamin E significantly elevated serum albumin in cows. Elevation of ALT and AST might be a consequences of hepatic necrosis (Bollard $e t$ al., 2009), or liver cell damage (Soltan et al., 2008). In the present study, vitamin $E$ had significantly $(\mathrm{P}<0.05)$ reduced ALT level in 500 E group. This was go along with Yusuf et al. (2019) in goat kids. Moreover, there was a significant $(\mathrm{P}<0.05)$ reduction in serum AST level in both treatments $300 \mathrm{E}$ and $500 \mathrm{E}$ groups. The result was disagree with Yusuf et al., (2019) who concluded that vitamin $E$ caused non significant impact on AST level in serum. By comparison, vitamin $E$ had no significant influence on ALT and AST in $1000 \mathrm{E}$ group. The values of both AST and ALT in the three treatment groups 
are still in the normal range according to the research of Sharp and Corp, (2011).

An increase in the amount of serum cholesterol was an indicator for the elevation of free radical damage in the body (Bansal and Jaswal, 2009). Vitamin E in this study caused a significant $(p<0.001)$ reduction in the cholesterol levels in the three groups of $\alpha$-tocopherol. This was in agreement with Yusuf et al. (2019) in goat kids, whereas, in disagreement with Ziaei, (2015), who reported that vitamin $\mathrm{E}$ had a non-significant effect on the cholesterol levels in Raieni goat. Regarding LDL, supplementation of goat kids with 300 IU, 500 IU and 1000 IU had no significant impact on LDL levels in the treated groups, which was disagree with Netto et al. (2017) who concluded that vitamin $\mathrm{E}$ reduced LDL in Saanen goats. While, it was disagreed with Ziaei, (2015), who suggested that vitamin $\mathrm{E}$ had increased amounts of LDL in Raieni goats. However, the influence of vitamin $\mathrm{E}$ on HDL was significantly $(p<0.001)$ decreased HDL in the three groups of $\alpha$-tocopherol compared with the control. It was in disagreement with Ziaei, (2015) who proposed that vitamin E had increased HDL concentration in Raieni goats. Supplementation of $\alpha$-tocopherol had a highly significant $(\mathrm{P}<0.001)$ increased the level of vitamin $E$ in the serum of the various treated groups of $\alpha$-tocopherol, which concuring with Dobbelaar et al. (2010) and Anugu et al. (2013) in dairy heifers and ewes respectively.

Malondialdehyde is produced by lipid oxidation caused by oxidative damage (Mougeot et al., 2009). Vitamin E improved the oxidative status of the kids in the three groups of $\alpha$-tocopherol in the present study by decreasing the amount of MDA in serum. These outcomes were agree with the result of Yusuf et al. (2019) on goat kids. Whereas, it was in disagreement with the result of Bouwstra et al. (2008), who proposed that $\alpha$-tocopherol did not reduce MDA concentration in the blood of periparturient heifers. The reduction of MDA in erythrocytes could be due to inhibition of lipid peroxidation in erythrocyte membranes (Jena et al., 2013). Obviously, from the results, group $500 \mathrm{E}$ was the more effective treatment in improved the blood parameters than the other two treatments of vitamin E, except in reducing level of MDA, group $1000 \mathrm{E}$ reduced the amount of MDA more than group $500 \mathrm{E}$.

\section{IN CONCLUSION}

The results of this study suggested that dietary supplementation of vitamin $\mathrm{E}$ in the three treated groups showed improvement of RBC, HB, boosted the state of the immunity and serum vitamin $\mathrm{E}$ content. Whereas, it reduced albumin, TP, ALT, AST, cholesterol, and MDA. The results of haematological and biochemical parameters of the present study showed that the three levels of vitamin $\mathrm{E}$ had no adverse impact on haematological, biochemical metabolites, improved level of vitamin E content and MDA in serum. High enzymatic activity and low MDA concentration is a good indication on better antioxidants status in goat kids.

\section{REFERENCES}

Adebiyi, O.A.; Oludare, O.F.; Majekodunmi, B. and Adeniji, O.A. (2014): Effect of Vitamin E or Selenium on Blood Profile and Oxidative Stability of Turkey Meat. J. Anim. Pro. Adv, (4): 469-475.

Aitken, S.L.; Karcher, E.L.; Rezamand, P.; Gandy, J.C.; VandeHaar, M.J.; Capuco, A.V. and Sordillo, L.M. (2009): Evaluation of antioxidant and proinflammatory gene expression in bovine mammary tissue during the periparturient period. J. Dairy Sci. (92): 589-598.

Ansari, F.A.; Ali, S.N. and Mahmood, R. (2015): $\quad$ Sodium nitrite-induced oxidative stress causes membrane damage, protein oxidation, lipid 
peroxidation and alters major metabolic pathways in human erythrocytes. Toxico. in Vitro. (29): 1878-1886.

Anugu, S.; Petersson-Wolf, C.S.; Combs Jr, G. and Petersson, K.H. (2013): Effect of vitamin $\mathrm{E}$ on the immune system of ewes during late pregnancy and lactation. Small rumi. Research. (111): 83-89.

Bansal, M.P. and Jaswal, S. (2009): Hypercholesterolemia induced oxidative stress is reduced in rats with diet enriched with supplement from dunaliella salina Algae. Am. J. Biomed. Sci. (3): 196-204.

Bollard, M.E.; Contel, N.R.; Ebbels, T.M.; Smith, L.; Beckonert, O.; Cantor, G.H.; Lehman- McKeeman, L.; Holmes, E.C.; Lindon, J.C. and Nicholson, J.K. (2009): NMR-based metabolic profiling identifies biomarkers of liver regeneration following partial hepatectomy in the rat. J. Proteome Res. (9): 59-69.

Buege, J.A. and Aust, S.D. (1978):

Microsomal lipid peroxidation. In

Methods in enzymology. (52): 302-

310. Academic Press.

Bouwstra, R.J.; Goselink, R.M.A.; Dobbelaar, Nielen, P.M.; Newbold, J.R. and van Werven, T. (2008): The Relationship Between Oxidative Damage and Vitamin E Concentration in Blood, Milk, and Liver Tissue from Vitamin E Supplemented and Nonsupplemented Periparturient Heifers. J. Dairy Sci. (91): 977-987.

Castellini, C.; Mourvaki, E.; Dal Bosco, A. and Galli, F. (2007): Vitamin E biochemistry and function: A case study in male rabbit. Reprod. Domest. Anim. (42): 248-256.

Dobbelaar, P.; Bouwstra, R.J.; Goselink, R.M.; Jorritsma, R.; van den Borne, J.J. and Jansen, E.H. (2010): Effects of vitamin $E$ supplementation on and the association of body condition score with changes in peroxidative biomarkers and antioxidants around calving in dairy heifers. J. Dairy Sci. (93): 3103-3113.

Egbe-Nwiyi, T.N.; Nwaosu, S.C. and Salami, H.A. (2000): Haematological Values of Apparently Healthy Sheep and Goats as Influenced by Age and Sex in Arid Zone of Nigeria. Afr. J. Biomed. Res. (3):109-115.

Gharieb, M.M. and Moursi, M.K. (2013): Comparative Efficacy of Different Supplement Used to Reduce Heat Stress and Their Impact on Performance, Immunity and Some Biochemical Parameters in Broilers Chickens. Egypt. J. Vet. Sci. (44): 49 67.

Hoehler, D.; Frohlich, A.A. and Marquardt, R.R. (1998): Ex-traction of alphatocopherol from serum prior to reversed liquid chromatography. J.Agri. Food Chem. (46): 973-978.

Jena, B.P.; Panda, N.; Patra, R.C.; Mishra, P.K.; Behura, N.C. and Panigrahi, B. (2013): Supplementation of Vitamin E and $\mathrm{C}$ Reduces Oxidative Stress in Broiler Breeder Hens during Summer. Food and Nutri Sci. (4): 33-37.

Khan, Z.I.; Ashraf, M.; Ahmad, K.; Valeem. E.E. and Mcdowell, L.R. (2009): Mineral status of forage and its relationship with that of plasma of farm animals in southern Punjab, Pakistan. Pakistan. J. Bot. (41): 67-72.

Merck Sharp and Dohme Corp. (2011):

A subsidiary of Merck and Co., Inc.

Whitehouse Station, NJ, USA

Minetti, M.; Agati, L. and Malorni, W. (2007): The microenvironment can shift erythrocytes from a friendly to a harmful behavior: pathogenetic implications for vascular diseases Cardiov Res.(75): 21-28 .

Mougeot, F.; Perez-Rodriguez, L.; Sumozas, N. and Terraube, J. (2009): Parasites,condition, cellular immunity and carotenoid-based ornamentation in 
male red-legged partridge Alectoris rufa. J Avian Biol. (40): 67-74.

Netto, A.S.; Barcelos, B.; Cunha, J.A. and Zanetti, M.A. (2017): 673 Hematological and biochemical parameters of Saanen goats supplemented with selenium and vitamin $\mathrm{E}$ during the transition period. J. of Anim.Sci. (95): 329.

NRC (National Research Council). (2007): Nutrient Requirements of Small Ruminants. The National Academ. Press, Washington DC.

Opara, M.N.; Udevi, N. and Okoli, I.C. (2010): Haematological Parameters and Blood Chemistry Of Apparently Healthy West African Dwarf (Wad) Goats In Owerri, South Eastern Nigeria. New York Sci. J. (8): 68-72.

Rahmani, M.; Dehghan-banadaky, M. and Kamalyan, R. (2015): Comparison between feeding rumen-protected choline and Vitamin E on milk yield and blood metabolites in early lactation dairy cows. Anim. Produ. Sci. (17): 19-29.

Ramadan, S.G.A.; Mahboub, H.D.H.; Helal, M.A.Y. and Sallam, M.A. (2018): Effect of Vitamin $\mathrm{E}$ and Selenium on Performance and Productivity of Goats. Internatio. J. of Chem. and Biomedi. Sci. (4): 16-22.

Sharp, M. and Corp, D. (2011): A subsidiary of Merck and Co., Inc. Whitehouse Station, NJ, USA.

Shivappa, H.B.; Nayaka, B.; Umakantha, S.; Ruban, W.; Murthy, H.N.N. and Narayanaswamy, H.D. (2013): Performance and hematological parameters of broilers fed neem, turmeric, vitamin $\mathrm{e}$ and their combinations. J. Food Agric. (6): 483488 .
Shokrollahi, B.; Mansouri, M. and Amanlou, $H$. (2013): The effect of enriched milk with selenium and vitamin $\mathrm{E}$ on growth rate, hematology, some blood biochemical factors, and immunoglobulins of newborn goat kids. Biol Trace Elem Res. (153): 184190.

Smolders, G.; Vaneekeren, N. and Govearts, $W$. (2012): Effect of vitamin E and selenium and different types of milk on health and growth of organic goat kids. Tackling the Future Challenges of Organic Animal Husbandry. Proceedings of the 2nd OAHC, Hamburg/Trenthorst, Germany, Sep 12-14.

Sokol, C.L. and Medzhitov, R. (2010): Role of basophils in the initiation of Th2 responses. Current Opinion in Immunl. (22): 73-77.

Soltan, M.; Hanafy, A.; Soltan, M.A. and Wafa, M.I. (2008): Effect of replacing fish meal by a mixture of different plant protein sources in Nile tilapia (Oreochromis niloticus L.) diets. Glob. Vet. (2): 157-164.

Traber, M.G. and Stevens, J.F. (2011): Vitamins $\mathrm{C}$ and $\mathrm{E}$ : beneficial effects from a mechanistic perspective. Free Radicals in Biolo and Medici. (51): 1000-1013.

Xuan, N.H.; Loc, H.T. and Ngu, N.T. ( 2018): Blood biochemical profiles of Brahman crossbred cattle supplemented with different protein and energy sources. Veteri Worl. (11): 1021-1024.

Yusuf, A.O.; Raheem, A.A.; Sowande, O.S.; Adebayo, K.O.; Motsei, L. and Ayoola, A.A. (2019): Growth Performance and Physiological Status of Intensively raised West African Dwarf (WAD) Goats Supplemented with Dietary Antioxidants. Egypt. J. Vet. Sci. (50). 65-74.

Ziaei, N. (2015): Effect of selenium and vitamin $\mathrm{E}$ supplementation on reproductive indices and biochemical metabolites in Raieni goats. J. of Appl. Ani. Res. (43): 426-430. 
